clothing, it is likely that the increases in waist circumference are genuine.

Increases in waist circumference on current and future morbidity should be a cause for concern. One US study found that young people above the 90th centile for waist circumference had higher concentrations of low density lipoprotein cholesterol, triglycerides, and insulin and lower concentrations of high density lipoprotein cholesterol than young people below the 10th centile. ${ }^{14}$ It is not known how early in life the increases in waist circumference over the reference values from 1977 and 1987 are detectable in a contemporary population, although we have observed similar increases in children as young as 3 years (unpublished observations)

The increase in waist circumference was appreciably larger in females than in males, for reasons that are unclear. Energy intake has decreased to a similar extent in the sexes. ${ }^{7}$ It may be that levels of physical activity have decreased faster in females than in males, and central fatness may be related more to physical activity than to energy intake.

We thank the referee Peter Betts for his comments on the paper and the University of Loughborough and the Data Archive, University of Essex, for supplying the data.

Contributors: See bmj.com

Funding: HDM and SME were supported by the University of North London diversity and development fund. TJC was supported by Medical Research Council programme grant G9827821.

Competing interests: None declared.
Bundred P, Kitchener D, Buchan I. Prevalence of overweight and obese children between 1989 and 1998: population based series of cross sectional studies. BMJ 2001:322:326-8.

2 Chinn S, Rona R. Prevalence and trends in overweight and obesity in three cross sectional studies of British children, 1974-94. BMJ 2001;322:24-6.

3 Daniels SR, Khourty PR, Morrison JA. Utility of different measures of body fat distribution in children and adolescents. Am J Epidemiol 2000;152:1179-84.

4 Taylor RW, Jones IE, Williams SM, Goulding A. Evaluation of waist circumference, waist-to-hip ratio and the conicity index as screening tools for high trunk fat mass, as measured by dual-energy X-ray absorptiometry, in children aged 3-19 years Am I Clin Nutr absorptiometry,

2000;72:490-5.
McCarthy HD, Jarrett KV, Crawley HF. Development of waist circumference percentiles in British children aged 5.0-16.9 y. Eur J Clin Nutr 2001;55:902-7.

6 British Standards Institute. Body measurements of boys and girls from birth up to 16.9 years, BS7321. London: BSI, 1990.

Gregory J, Lowe S. National diet and nutrition survey, young people aged 4 to 18 years. London: Stationery Office, 2000.

8 World Health Organization. Physical status: the use and interpretation of anthropometry: a report of a WHO expert committee. Geneva: WHO, 1995.

9 Cole TJ, Freeman JV, Preece MA. Body mass index reference curves for the UK, 1990. Arch Dis Child 1995;73:25-9.

10 Maynard LM, Wisemandle W, Roche AF, Chumlea C, Guo SS, Siervogel RM. Childhood body composition in relation to body mass index. Paediatrics 2001;107:344-50.

11 Caprio S, Hyman LD, McCarthy S, Lange R, Bronson M, Tamborlane WV. Fat distribution and cardiovascular risk factors in obese adolescent Virls: importance of the intrabblominal fat depot. Am J Clin Nutr 1996:64:12-7.

12 Moreno LA, Fleta J, Mur L, Sarria A, Bueno M. Fat distribution in obese and non-obese children and adolescents. J Paedr Gastr Nutr 1998;27:17680.

13 Moreno LA, Fleta J, Sarria A, Rodriguez G, Gil C, Bueno M. Secular changes in body fat patterning in children and adolescents of Zaragoza (Spain), 1980-1995. Int J Obesity 2001;25:1656-60.

14 Freedman DS, Serdula MK, Srinivasan SR, Berenson GS. Relation of circumferences and skinfold thicknesses to lipid and insulin concentrations in children and adolescents: the Bogalusa Heart Study. Am J Clin Nutr 1999;69:308-17.

(Accepted 22 January 2003)
Centre for Public

Policy and

Management,

University of

St Andrews, Fife

KY16 9AL

Huw T O Davies

professor of health

care policy and

management

Claire-Louise

Hodges

research fellow

Division of Health

Policy and

Management,

University of

California, Berkeley,

CA 94720, USA

Thomas G Rundall

Henry J Kaiser

professor of organised

health systems

Correspondence to:

H T O Davies

hd@st-and.ac.uk

BMJ 2003;326:626-8

\title{
Views of doctors and managers on the doctor-manager relationship in the NHS
}

\author{
Huw T O Davies, Claire-Louise Hodges, Thomas G Rundall
}

A well functioning relationship between doctors and managers is crucial if government plans for "modernising" the NHS are to deliver real service improvements. ${ }^{2}$ We aimed to shed some light on current perceptions of the doctor-manager relationship by examining areas of convergence or divergence of views among a large sample of doctors and managers in the NHS.

\section{Participants, methods, and results}

We conducted a postal questionnaire survey in NHS acute trusts across Great Britain during the summer of 2002. The survey included a census of chief executives and medical directors (from 197 trusts), together with a stratified cluster sample of both medical and non-medical managers at directorate level (clinical directors or their equivalent and non-medical directorate managers or their equivalent) randomly selected from 75 trusts. Comparisons between these different role groups form the central part of the analysis; we assessed variations across all four groups using $\chi^{2}$ tests.

We received replies from 103 chief executives, 168 medical directors, 445 clinical directors (or equivalent), and 376 non-medical directorate managers (or equivalent). The response rate was $66 \%$ at board level and $73 \%$ at directorate level, giving a total of 1092 respondents.

Overall, chief executives were the most optimistic about the state of doctor-manager relationships, and clinical directors the least. About three quarters $(78 / 103,76 \%)$ of chief executives rated the quality of current doctor-manager relationships as 4 or more on a scale of 1 (poor) to 5 (excellent), compared with just $37 \%(164 / 443)$ of clinical directors. Further, $78 \%$ (80/ 102) of chief executives thought that doctor-manager relationships would improve over the next year, compared with just 28\% (123/439) of clinical directors (indeed, 26\% (113/439) of clinical directors thought that the relationships would deteriorate). Differences across all four groups were significant at $\mathrm{P}<0.01$.

Questions about specific aspects of the doctormanager relationship showed some areas of good agreement but also highlighted issues where views diverged significantly between the four groups (table). Only rarely was the most obvious divide between those medically qualified and those not. More often, the dif- 
Agreement with statements about doctor-manager relationships among 1092 survey respondents. Values are the percentages (numbers) of respondents in each group who agreed with given statement

\begin{tabular}{|c|c|c|c|c|c|}
\hline Statements & $\begin{array}{l}\text { Chief executives } \\
(\mathrm{n}=103)\end{array}$ & $\begin{array}{l}\text { Medical directors } \\
\quad(\mathrm{n}=168)\end{array}$ & $\begin{array}{l}\text { Directorate managers } \\
\qquad(\mathrm{n}=\mathbf{3 7 6})\end{array}$ & $\begin{array}{l}\text { Clinical directors } \\
(\mathrm{n}=\mathbf{4 4 5 )}\end{array}$ & $\begin{array}{c}\text { Overall } \\
(\mathrm{n}=1092)\end{array}$ \\
\hline \multicolumn{6}{|l|}{ Issues of relative power } \\
\hline $\begin{array}{l}\text { The relative power and influence between management and medical staff } \\
\text { is about right }\end{array}$ & $74(75)$ & $73(123)$ & 54 (199) & 45 (198) & $55(595)$ ** \\
\hline Doctors are adequately involved in hospital management activities & $78(79)$ & $75(124)$ & $68(253)$ & $63(282)$ & $68(738)$ ** \\
\hline Doctors have sufficient influence on hospital management & $92(95)$ & $77(127)$ & $87(320)$ & $48(211)$ & $70(753)$ ** \\
\hline $\begin{array}{l}\text { Managers allow doctors sufficient autonomy to practise medicine } \\
\text { effectively }\end{array}$ & $97(99)$ & $95(157)$ & $95(354)$ & $73(317)$ & $86(927)$ * \\
\hline Management do not exert pressure to reduce use of tests or services $\dagger$ & $75(76)$ & $88(147)$ & $83(306)$ & $76(330)$ & $80(859)$ ** \\
\hline Management do not exert pressure to discharge or transfer patients early† & $50(51)$ & $52(87)$ & 49 (179) & $55(241)$ & $52(558)$ \\
\hline \multicolumn{6}{|l|}{ Perceptions of staff calibre } \\
\hline Management staff in this hospital are consistently of high quality & $81(82)$ & $70(114)$ & $78(292)$ & $53(232)$ & $67(720)$ ** \\
\hline Medical staff in this hospital are consistently of high quality & $92(94)$ & $91(148)$ & $85(316)$ & 90 (397) & $88(955)$ * \\
\hline Managers are well versed in clinical activity & $84(85)$ & $76(124)$ & $83(311)$ & $47(206)$ & $68(726)$ ** \\
\hline Managers have confidence in clinical leadership capabilities & $68(70)$ & $67(111)$ & $69(253)$ & $71(310)$ & $69(744)$ \\
\hline Doctors have confidence in management leadership capabilities & $87(89)$ & $63(105)$ & $55(202)$ & $42(184)$ & $54(580)$ ** \\
\hline \multicolumn{6}{|l|}{ Views on goals, decision making, and team working } \\
\hline $\begin{array}{l}\text { Hospital managers and doctors are largely in agreement on the overall } \\
\text { goals of the institution }\end{array}$ & $96(99)$ & $83(140)$ & $81(302)$ & $78(343)$ & $81(884)$ ** \\
\hline Management is driven more by clinical rather than financial priorities $\dagger$ & $78(80)$ & $44(71)$ & $53(197)$ & $24(104)$ & $42(452)$ ** \\
\hline Managers and doctors focus together on patient need & $87(88)$ & $80(134)$ & $82(306)$ & $61(267)$ & $74(795)$ ** \\
\hline Doctors view the management decision making process to be fair & $74(75)$ & $60(99)$ & $40(148)$ & $36(159)$ & $45(481)^{* *}$ \\
\hline Doctors generally are supportive of management decisions & $90(93)$ & 77 (127) & $64(231)$ & $52(224)$ & $63(675)$ ** \\
\hline Doctors and managers work well together as a team & $91(94)$ & $87(141)$ & $82(303)$ & $73(315)$ & $80(853)$ ** \\
\hline $\begin{array}{l}\text { Continuous improvement is undertaken on the basis of partnership and } \\
\text { teamwork }\end{array}$ & 90 (92) & $79(131)$ & $82(305)$ & $70(303)$ & $78(831)$ ** \\
\hline \multicolumn{6}{|l|}{ Communication issues } \\
\hline $\begin{array}{l}\text { Management is good at providing feedback to doctors about service } \\
\text { delivery }\end{array}$ & $75(76)$ & $63(104)$ & $73(272)$ & $51(223)$ & $63(675)$ ** \\
\hline $\begin{array}{l}\text { Doctors are good at keeping management informed about service } \\
\text { development issues }\end{array}$ & $66(67)$ & $55(93)$ & $42(155)$ & $56(246)$ & $52(561)$ ** \\
\hline $\begin{array}{l}\text { The use of clinical performance data stimulates good practice and } \\
\text { strengthens service management }\end{array}$ & $93(96)$ & $86(142)$ & $84(310)$ & $74(321)$ & $81(869)$ ** \\
\hline $\begin{array}{l}\text { The availability of clinical performance data improves the doctor-manager } \\
\text { relationship }\end{array}$ & $83(84)$ & $73(121)$ & $70(257)$ & $61(266)$ & $68(728)$ ** \\
\hline \multicolumn{6}{|l|}{ Resource issues } \\
\hline There is an adequate number of consultants to provide quality patient care & $32(33)$ & $24(39)$ & $41(153)$ & $14(62)$ & $27(287)$ ** \\
\hline Within this organisation there are generally sufficient clinical resources & $24(25)$ & $18(29)$ & $25(92)$ & $9(38)$ & $17(184)$ ** \\
\hline $\begin{array}{l}\text { Management is generally responsive to requests for additional clinical } \\
\text { resources }\end{array}$ & $86(87)$ & $69(114)$ & $76(282)$ & $38(167)$ & $61(650)$ ** \\
\hline $\begin{array}{l}\text { Doctors prioritise effectively when making requests for additional } \\
\text { resources }\end{array}$ & $39(40)$ & $32(53)$ & $23(86)$ & $47(204)$ & $36(383)$ * * \\
\hline
\end{tabular}

Some denominators are reduced because of missing data (never more than $3 \%$ for any individual question).

${ }^{*} \mathrm{P}<0.05$ for $\chi^{2}$ test of equality across groups.

${ }^{* *} P<0.01$ for $\chi^{2}$ test of equality across groups.

†These statements were "reverse worded," and values have been adjusted accordingly.

ferences were between senior managers (board level) and middle managers (directorate level). Most striking was that clinical directors often seemed to have views markedly divergent from-and much less positive than-the views held across the other three groups.

Typically, clinical directors were the least impressed with management and the most dissatisfied with the role and influence of clinicians. For example, whereas almost all (95\% (610/640)) chief executives, medical directors, and directorate managers agreed that "managers allow doctors sufficient autonomy to practise medicine effectively," $27 \%$ of clinical directors disagreed. Further, as a group, clinical directors were less likely $(\mathrm{P}<0.01)$ than each of the other groups to agree that "management staff in this hospital are consistently of high quality" (53\% v 77\% (average across the other three groups)), that "managers are well versed in clinical activity" (47\% v 81\%), and that "doctors have sufficient influence on hospital management" (48\%v $85 \%$ ). Indeed, for almost all positive statements about doctor-manager relationships at least a quarter of clinical directors disagreed. The only statement that received near unanimous approval from clinical directors $(90 \%)$ was "medical staff in this hospital are consistently of high quality."

\section{Comment}

Doctors and managers in the NHS are often dissatisfied with doctor-manager relationships but differ in their views depending on their role in the organisation. In general, senior managers were more positive than staff at directorate level, and lay managers were more positive than medical managers. Clinical directors (or those in equivalent roles) were easily the most disaffected, with many holding negative opinions about managers' capabilities, the respective balance of power and influence between managers and clinicians, and the prospects for improved relations. Unless such divergence is addressed, further difficulties in delivery 
of the government's ambitious agenda for modernisation are likely. ${ }^{3}$

Contributors: HTOD and TGR designed the study; C-LH collected the data and did the analysis; HTOD led on writing the paper, with substantial contributions from TGR and C-LH. HTOD acts as guarantor.

Funding: Nuffield Trust, London, and the Commonwealth Fund, New York. The guarantor accepts full responsibility for the conduct of the study, had access to the data, and controlled the decision to publish.

Competing interests: None declared.

1 Edwards N, Marshall M. Doctors and managers. BMJ 2003;326:116-7.

2 Protopsaltis G, Fulop N, Edwards N, Meara R. Failure and turnaround. London: NHS Confederation, 2003 .

3 McLellan A. A nasty kick in the ballots. Health Serv J 2002: 14 November, pp18-19.

(Accepted 4 March 2003)
Department of

Medicine, Division

of Infectious

Diseases, Karolinska

Institute, Karolinska

Hospital, S-171 76

Stockholm, Sweden

Anna Färnert

medical doctor

Mita M Thapar

PhD student

Anders Björkman

professor

Sándor Berezcky

PhD student

Department of

Infectious Diseases,

Sahlgrenska

University Hospital,

Östra, Gothenburg,

Sweden

Johan Lindberg

associate professor

Department of

Pharmaceutical

Biosciences,

Division of

Microbiology,

Uppsala University,

Uppsala, Sweden

Göte Swedberg

associate professor

Centro de Malária e

outras Doencas

Tropicais, Instituto

de Higiene e

Medicina Tropical,

Universidade Nova

de Lisboa, Lisboa,

Portugal

Pedro Gil

post doctoral

researcher

Department of

Clinical Chemistry,

Falun Central

Hospital, Falun and

Dalarna University

College, Borlänge,

Sweden

Yngve Berqvist

associate professor

Niklas Lindegårdh

PhD student

Correspondence to:

A Färnert

anna.farnert@

medks.ki.se

BMJ 2003;326:628-9

\section{Evidence of Plasmodium falciparum malaria resistant to atovaquone and proguanil hydrochloride: case reports}

Anna Färnert, Johan Lindberg, Pedro Gil, Göte Swedberg, Yngve Berqvist, Mita M Thapar, Niklas Lindegårdh, Sándor Berezcky, A Björkman

The increased spread of drug resistant malaria highlights the need for alternatives for treatment and chemoprophylaxis. The combination of atovaquone and proguanil hydrochloride (Malarone, GlaxoSmithKline, NC) has shown high efficacy against Plasmodium falciparum with only mild side effects and has been registered for use in several countries, including Denmark, Germany, Sweden, the United Kingdom, and the United States. ${ }^{1}$ Treatment failures have been attributed to suboptimal dosage, reinfections, or to a point mutation in the cytochrome $b$ gene. ${ }^{12}$ Bioavailability of atovaquone depends on the concomitant intake of a fatty diet, yet drug concentrations were not analysed in these reports. We provide evidence of resistance in two

Details of three patients treated with atovaquone and proguanil hydrochloride (Malarone; GlaxoSmithKline) for Plasmodium falciparum malaria

\begin{tabular}{|c|c|c|c|c|}
\hline \multirow[b]{2}{*}{ Patients' details } & \multirow[b]{2}{*}{ Infected erythrocytes (\%) } & \multirow[b]{2}{*}{ No of tablets } & \multicolumn{2}{|c|}{ Gene mutations* } \\
\hline & & & Cytochrome b & Dihydrofolate reductase \\
\hline \multicolumn{5}{|l|}{ Case 1 (11 kg) } \\
\hline Day of presentation & 1 & 2 & Wild type & Wild type \\
\hline \multicolumn{5}{|c|}{ Days after presentation: } \\
\hline 1 & 5 & 1 & & \\
\hline 2 & 4 & Mefloquine $\dagger$ & & \\
\hline 4 & Gametocytes only & & & \\
\hline 7 & Gametocytes only & & Wild type & Wild type \\
\hline 28 & 0 & & & \\
\hline \multicolumn{5}{|l|}{ Case $2(19 \mathrm{~kg})$} \\
\hline Day of presentation & 0.5 & 1 & Mutant type 1 & Wild type \\
\hline \multicolumn{5}{|c|}{ Days after presentation: } \\
\hline 1 & & 1 & & \\
\hline 2 & 0.2 & 1 & & \\
\hline 4 & Gametocytes only & & Negative & Negative \\
\hline 7 & Gametocytes only & & Negative & Negative \\
\hline 28 & 1.6 & Mefloquine† & Mutant type 1 & Mutant type 2 \\
\hline \multicolumn{5}{|l|}{ Case 3 (101 kg) } \\
\hline Day of presentation & Few rings & 4 & Mutant type 1 & Wild type \\
\hline \multicolumn{5}{|c|}{ Days after presentation: } \\
\hline 1 & & 4 & & \\
\hline 2 & 0 & 4 & & \\
\hline 3 & Gametocytes only & & Mutant type 1 & Negative \\
\hline 7 & Gametocytes only & & Mutant type 1 & Negative \\
\hline 28 & 0 & & Negative & Negative \\
\hline
\end{tabular}

Mutant type 1=locus 268-Ser. Mutant type 2=loci 51-Ile, 59-Arg, and 108-Asn.

${ }^{*}$ Detected by polymerase chain reaction.

tRescue treatment. patients treated with atovaquone and proguanil hydrochloride for P falciparum infection.

\section{Methods and results}

In September 2000, two boys and their mother were diagnosed as having $P$ falciparum malaria at the university hospital in Gothenburg, after returning from an eight week visit to the Ivory Coast. They had taken chloroquine weekly and proguanil daily for chemoprophylaxis against malaria. Case 1, the youngest boy (18 months), had fever, convulsions, and 1\% infected erythrocytes. He was treated with atovaquone and proguanil hydrochloride (table). His fever continued, and 